\title{
Environmental Risk Factors for Sarcoidosis
}

\author{
Marc A. Judson * \\ Albany Medical College, Albany, NY, United States
}

OPEN ACCESS

Edited by:

Philippe Saas,

INSERM U1098 Interactions

Hôte-Greffon-Tumeur \& Ingénierie

Cellulaire et Génique, France

Reviewed by:

Gernot Zissel,

University of Freiburg, Germany

Peter Korsten,

Nephrology and Rheumatology

University Medical Center

Göttingen, Germany

*Correspondence:

Marc A. Judson

judsonm@amc.edu

Specialty section:

This article was submitted to Inflammation,

a section of the journal

Frontiers in Immunology

Received: 06 March 2020

Accepted: 26 May 2020

Published: 26 June 2020

Citation:

Judson MA (2020) Environmental Risk

Factors for Sarcoidosis.

Front. Immunol. 11:1340

doi: 10.3389/fimmu.2020.01340
Sarcoidosis is a multisystem granulomatous disease that may affect any body organ. Sarcoidosis is associated with many environmental and occupational exposures. Because the exact immunopathogenesis of sarcoidosis is unknown, it is not known whether these exposures are truly causing sarcoidosis, rendering the immune system more susceptible to the development of sarcoidosis, exacerbating subclinical cases of sarcoidosis, or causing a granulomatous condition distinct from sarcoidosis. This manuscript outlines what is known about the immunopathogenesis of sarcoidosis and postulates mechanisms whereby these exposures could cause or exacerbate the disease. We also describe the varied environmental and occupational exposures that have been associated with sarcoidosis. This includes potential infectious exposures such as mycobacteria and Propionibacterium acnes, a skin commensal bacterium, as well as non-infectious environmental exposures including inhaled bioaerosols, metal dusts and products of combustion. Further insights concerning the relationship of environmental exposures to the development of sarcoidosis may have a major impact on the prevention and treatment of this enigmatic disease.

Keywords: sarcoidosis, antigen, environment, infection, immunity

\section{INTRODUCTION}

Sarcoidosis is a multisystem granulomatous disease of unknown cause. The lung is the most common organ involved with sarcoidosis at a frequency of $\sim 90$ percent $(1,2)$. The skin, eyes, peripheral lymph nodes and liver are also commonly involved $(1,2)$. Unlike sarcoidosis, the causes of many granulomatous diseases are known. Exposures that may cause granulomatous inflammation include mycobacteria and fungi that may cause granulomatous infection, $(3,4)$ bioaerosols including bird antigens that cause hypersensitivity pneumonitis (5) and metals including beryllium that causes chronic beryllium disease (CBD) (6). It is plausible that sarcoidosis is caused by one or several antigen exposures that initiates and possibly perpetuates the granulomatous process. Several environmental exposures have been linked to sarcoidosis. Because these exposures are disparate, they may lead to the development of sarcoidosis via different mechanisms; and in fact, it is possible that sarcoidosis represents a conglomeration of several dissimilar diseases ["the sarcoidoses" (7)]. This manuscript will explore environmental risk factors for sarcoidosis. We will briefly describe the potential role of environment antigens in leading to the granulomatous inflammation of sarcoidosis, and then focus on the available evidence supporting an association of specific environmental exposures with the development of sarcoidosis. 


\section{OVERVIEW OF IMMUNOPATHOGENESIS OF SARCOIDOSIS RELATIVE TO ENVIRONMENTAL RISK FACTORS}

Environmental exposures are postulated to be associated with the development of sarcoidosis in four general ways. The first mechanism involves the detection and processing of antigen by antigen presenting cells such as macrophages and dendritic cells. These processed antigens are subsequently presented via human leukocyte antigen (HLA) Class II molecules to a restricted set of $\mathrm{T}$-cell receptors on naive $\mathrm{T}$ lymphocytes that are primarily of the $\mathrm{CD}^{+}$class (8). An interplay of antigen, HLA class II molecules, and T-cell receptors occurs at the HLA molecule binding site and is thought to be essential for sarcoidosis to develop (9). These events induce a polarization of the $\mathrm{T}$ lymphocytes to a Th1/Th17 phenotype, (10) followed by cellular recruitment, proliferation, and differentiation leading to formation of the sarcoid granuloma. This mechanism is thought to be common across most granulomatous lung diseases known to be caused by a specific antigen, and therefore it is possible that the immune system may not be dysregulated in this instance.

There is a large body of evidence to support this proposed mechanism for the immunopathogenesis of sarcoidosis. Various HLA gene alleles have been associated with development of sarcoidosis, $(11,12)$ protection from developing sarcoidosis, (11, $12)$ and specific disease phenotypes $(11,12)$. Further analyses have suggested that such HLA gene polymorphisms result in conformational changes in the antigen binding pockets of HLA molecules (13). Additional evidence supporting this proposed mechanism for sarcoidosis relates to CBD, a phenotypic mimic of sarcoidosis both radiographically and pathologically, $(14,15)$ which is associated with specific amino acid substitutions in the HLA molecule $(16,17)$ Beryllium-specific oligoclonal CD4+ T lymphocytes recognize beryllium within HLA molecules with these amino acid substitutions and this recognition leads to CD4+ lymphocyte proliferation, recruitment of other T cells and monocytes to the lung, (18) and the production of Th1/Th17 cytokines that eventually results in granuloma formation (18, 19). Further indirect support of this mechanism of sarcoidosis granuloma formation is that the lung and the skin are the two most common organs involved with sarcoidosis when the disease is clinically isolated to one organ (20). The skin and the lung are particularly conductive sites for antigen capture (21) and adaptive immune responses (22). It may be that these two organs are the main "portal of entry" for antigens that elicit the sarcoidosis granulomatous response, with further organ involvement requiring dissemination of antigen and/or other inflammatory mechanisms, (20) such as T-cell homing (23).

Although there is abundant evidence supporting the aforementioned mechanism of antigen-induced granulomatous inflammation in sarcoidosis, this mechanism is inconsistent with several available clinical and epidemiologic data. First, the associations between various HLA alleles and sarcoidosis phenotypes are not universal, but rather ethnicity-specific $(11,12,24)$. Second, although sarcoidosis patients with specific phenotypic features of sarcoidosis have statistically higher percentages of certain HLA alleles than sarcoidosis patients without those specific phenotypic features or the general population, a significant percentage of individuals in these latter two groups carry the allele of risk $(12,25)$. In addition, most of these allele-specific phenotypes explain a small minority of cases $(12,13,25)$. Another criticism of this mechanism is that it is problematic to account for the systemic features of sarcoidosis. The granulomas of sarcoidosis are often found in multiple and disparate organs. It is unclear how causative sarcoidosis antigens could disseminate throughout the body.

The second mechanism by which environmental antigens may induce a granulomatous response in sarcoidosis involves dysregulation of the immune system leading to autoimmunity. Evidence is accumulating that autoimmunity may be involved in some forms of sarcoidosis (26-30). Autoimmunity in sarcoidosis may occur via molecular mimicry whereby antigens trigger inflammation leading to exposure of self-peptides (31). Immunologic similarities between the "foreign" trigger and the "self" peptide promote autoreactive $\mathrm{T}$ or $\mathrm{B}$ cells in a susceptible individual. It is possible that the initial granulomatous reaction in sarcoidosis is a direct consequence of an antigen exposure in a target organ, but that subsequent granulomatous reactions in other organs are the result of molecular mimicry. This mechanism might explain how sarcoidosis manifests as a systemic disease without the need for a putative antigen to disseminate throughout the body. The best evidence for autoimmunity has been demonstrated in Lofgren's syndrome, a self-limiting form of the sarcoidosis where independent groups have identified vimentin as a possible autoantigen using proteomic techniques on lung macrophages and homogenized spleen tissue (32-36). Molecular mimicry may also by alteration of the binding pocket of the HLA molecule causing a granulomatous reaction to self-antigens. This mechanism appears to be relevant in the case of chronic beryllium disease, (37) and may explain other associations of metal exposures to the development of sarcoidosis or sarcoidosis-like reactions (vide infra). Antinuclear antibodies have been found in more than one-quarter of sarcoidosis patients in some cohort, suggesting autoimmunity may occur in sarcoidosis and may cause overlap syndromes with connective tissue diseases (38). Another form of "autoimmunity" could occur from autophagy that has been shown to promote MHC-II (major histocompatibility complexII) presentation of proteins from intracellular sources (39). Perhaps environmental antigens first stimulate HLA molecules that interact with intracellular proteins as the result of autophagy.

A third mechanism by environmental exposures may induce sarcoidosis is by acting as an adjuvant and/or as a nonspecific stimulator/dysregulator of the immune system. Such a mechanism would not directly cause sarcoidosis but would render the immune system more susceptible to another antigen or mechanism that could cause sarcoidosis. Such a mechanism may be analogous to a drug-induced sarcoidosis (DISR) like reaction that occurs with immune checkpoint inhibitor (ICI) therapy (40). ICIs are drugs that not only enhance anti-tumor activity, but also stimulate the immune system resulting in numerous immune-related adverse events (irAEs) One of several of these irAEs is a DISR, although $<10 \%$ of irAEs were DISRs in one series (41). It is therefore plausible that ICIs are not 
stimulating the immune system specifically to cause sarcoidosis but enhancing the risk of sarcoidosis in susceptible individuals.

Finally, environmental exposures that are epidemiologically associated with sarcoidosis may not be involved in any mechanism of disease development, as association does not prove causation. Figure 1 outlines the possible mechanisms to explain the association of environmental exposures to sarcoidosis.

\section{THE ROLE OF GENETICS}

The aforementioned discussion concerning the relationship between sarcoidosis and potential environmental exposures is incomplete without a discussion of the importance of genetics. It is hypothesized that a combination of genetic and environmental factors contribute to the development of sarcoidosis (42). A recent large familial aggregation study showed that heritability of the disease was 39\%, (43) suggesting that genetic variation is an important contributing factor to the risk of sarcoidosis. Various HLA polymorphisms have been associated with development of sarcoidosis, protection from sarcoidosis and certain phenotypic expressions of sarcoidosis $(11,13)$. In addition, genome-wise association studies have reported variations numerous non-HLA genes that are associated with sarcoidosis. These include annexin A11 (44) that is involved in cell division and apoptosis, NOTCH4 (45) that regulates the activity of $\mathrm{T}$ cell immune responses, and BTNL2 $(45,46)$ that is involved in $\mathrm{T}$ cell activation. We suspect that many of the aforementioned mechanisms described concerning the association of environmental exposures to sarcoidosis depend on specific genetic factors. We envision that in the future, the etiology of sarcoidosis will be personalized whereby certain genetics traits present in an individual will suggest that certain specific exposures will place the subject at risk of developing sarcoidosis.

\section{POTENTIAL INFECTIOUS CAUSES OF SARCOIDOSIS}

Infectious agents have been suspected as being a possible cause of sarcoidosis. However, data supporting this conjecture are inconsistent and unconvincing. There is an abundance of indirect evidence that mycobacteria are involved in the development of sarcoidosis. Two meta-analyses of studies evaluating infectious agents as a cause of sarcoidosis have suggested an etiologic link between mycobacteria and sarcoidosis $(47,48)$. Molecular techniques have identified mycobacterial components in sarcoidosis tissues in some (49-51) but not all (52, 53) studies. Mycobacterial catalase-peroxidase protein (mKatG) has been identified in sarcoidosis tissues. $\mathrm{mKatG}$ has similar physicochemical properties to the Kveim-Siltzbach reagent that induces granulomatous inflammation almost exclusively in

(1)

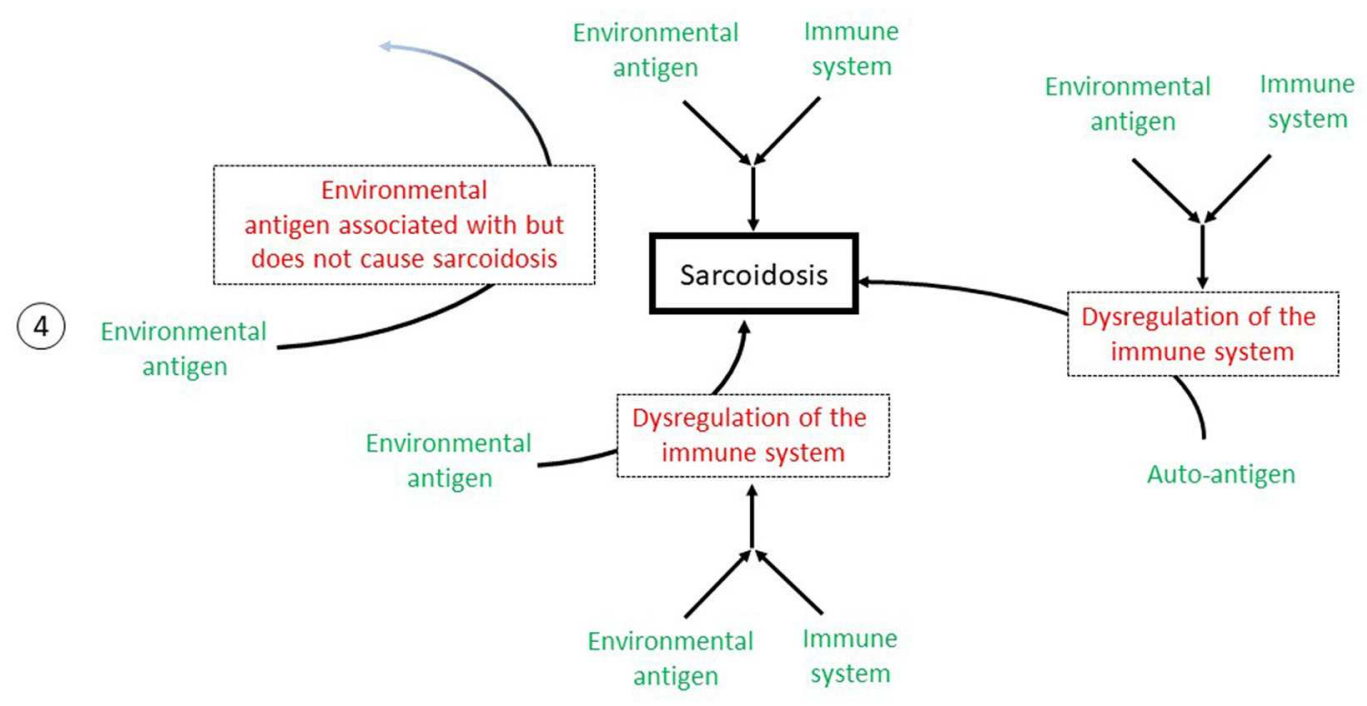

FIGURE 1 | A depiction of the possible mechanisms to explain the association of environmental exposures to sarcoidosis. 1: The environmental exposure may act as an antigen to stimulate the immune system to directly cause sarcoidosis. The immune system is functioning normally with a appropriate response to the antigen. 2 : The antigen interacts with the immune system to cause its deregulation. The immune system then acts abnormally to cause sarcoidosis. 3: The antigen acts as an adjuvant that acts as an adjuvant to stimulate or dysregulate the immune system but not directly cause sarcoidosis. However, the immune system is now "primed" such that another antigen or stimulus can now interact with the immune system to cause sarcoidosis. 4: The environmental exposure is a cofounder. Although this exposure is associated with sarcoidosis, it does not cause sarcoidosis. 
sarcoidosis patients (54) T-cell responses to $\mathrm{mKatG}$ have been demonstrated in peripheral blood monocytes of sarcoidosis patients $(55,56)$ with even more robust $\mathrm{T}$-cell responses in bronchoalveolar lavage fluid $(55,57)$ and strongest responses in those with active disease $(55,57)$ Similar findings have not been demonstrated in other lung diseases $(55,57)$. It should be noted that the demonstration of mycobacterial antigens in sarcoidosis patients and granulomatous immune responses to mycobacterial antigens does not imply that sarcoidosis is a form of mycobacterial infection. Rather, it may be that some poorly degraded mycobacterial antigens contribute to the immune process of sarcoidosis without the presence of viable invasive mycobacterial organisms (48).

There is abundant evidence that Propionibacterium acnes, a skin commensal bacterium, is associated with sarcoidosis. This microorganism is the only one that has been cultured from sarcoidosis lesions $(58,59)$. Numerous studies have identified specific immune responses to Propionibacterium acnes in sarcoidosis patients but much less to none in nonsarcoidosis controls $(52,60,61)$. Propionibacterium acnes was highly associated with sarcoidosis in a meta-analysis of studies evaluating infectious agents as a cause of the disease (47).

Numerous other infectious agents have been implicated in the immunopathogenesis of sarcoidosis. Several of these infectious agents are listed in Table 1. Implicated infectious agents include bacteria, mycobacteria, and fungi.

Several trials of antibiotics for sarcoidosis have targeted suspected infectious pathogens. Therapy with concomitant levofloxacin, ethambutol, erythromycin and rifampin (CLEAR) has been used for the treatment of sarcoidosis by targeting presumed mycobacterial pathogens. An open label trail of CLEAR for pulmonary sarcoidosis showed an improvement in forced vital capacity in 8 of the 15 enrolled patients who were able to tolerate the study drugs for the full 8 weeks of the study (72). A subsequent small $(N=29)$ single-blind placebo-control trial of the CLEAR regimen for cutaneous sarcoidosis showed a statistically significant greater reduction in lesion size with CLEAR than placebo (73). A larger randomized double-blind placebo-controlled trial of CLEAR for pulmonary sarcoidosis is currently underway. Several case series of tetracyclines, including doxycycline and minocycline, have been reported as effective for cutaneous sarcoidosis $(74,75)$. These reports were unblinded descriptions of treated cases without comparisons with a control group. Furthermore, it is unclear if the mechanism of action of

TABLE 1 | Selected infectious agents associated with sarcoidosis*.

\begin{tabular}{lccc}
\hline Infectious agents & Immunologic & Molecular & Culture \\
\hline Mycobacterium tuberculosis & $\sqrt{ }(50,55,62)$ & $\sqrt{ }(49,56,63)$ & \\
Other Mycobacteria & $\sqrt{ }(57,64)$ & $\sqrt{ }(49,51)$ & \\
Propionibacterium acnes & $\sqrt{ }(52,65,66)$ & $\sqrt{ }(60)$ & $\sqrt{ }(58,59)$ \\
Fungi & $\sqrt{ }(67,68)$ & & \\
Borrelia & $\sqrt{ }(69)$ & $\sqrt{ }(70,71)$ & \\
\hline
\end{tabular}

${ }^{\star}$ References are in parentheses. these tetracyclines was antibacterial or anti-inflammatory (76). Case reports and case series have shown a benefit from with clarithromycin for presumed Propionibacterium acnes infection in sarcoidosis patients, (77) as well as a benefit from empiric anti-fungal therapy (78). However, these reports also contained no control patients and/or were poorly designed to rigorously demonstrate a clinically relevant endpoint. In summary, the available evidence does not clearly demonstrate that therapy vs. a specific infectious pathogen is useful for the treatment of sarcoidosis. As previously mentioned, this does not exclude infectious organisms being involved in the immunopathogenesis of sarcoidosis, as an antigen of a microorganism may stimulate the immune system in ways that promote the granulomatous inflammation of sarcoidosis.

Besides examining individual infectious pathogens as causes of sarcoidosis, human microbiotica may have an important role in disease development. Human microbiotica regulate several physiological processes including metabolic functions and immune homeostasis (79). Alterations in the gut and respiratory microbiome have been associated with several inflammatory diseases including autoimmune diseases and cancer (80-83). It is plausible that sarcoidosis may be associated with specific changes in the composition of lung or gut microbiotica. However, a few studies examining changes in the lung microbiome have failed to identify distributions that are specific for sarcoidosis $(84,85)$. One recent study did suggest that Atopobium and Fusobacterium may be associated with sarcoidosis, (86) and another found that microbiota in bronchoalveolar lavage of sarcoidosis patients was less diverse and abundant compared to healthy controls (87). However, it is unclear whether these changes in the lung microbiome are causing sarcoidosis or are a result of the disease.

\section{POTENTIAL NON-INFECTIOUS ENVIRONMENTAL RISK FACTORS FOR SARCOIDOSIS}

There are numerous non-infectious environmental risk factors associated with sarcoidosis. These risk factors include working in various occupations, exposure to various substances, and dwelling in particular environments (Table 2). Most of these associations are epidemiologic. Numerous epidemiologic studies have demonstrated that sarcoidosis occurs most commonly in the Spring season (88-91). This suggests that some sarcoidosis cases may result from inhalation of an organic bioaerosol that is more abundant in the springtime, possibly analogous to summer-type hypersensitivity which is a form of hypersensitivity pneumonitis in Japan caused by inhalation of certain fungi that reach high concentrations in the summer air (113). Several other epidemiologic analyses have found that the prevalence of sarcoidosis is associated with exposure to other organic bioaerosols such as exposure to musty odors at the workplace (103) and exposure to industrial organic dusts $(104,105)$.

Sarcoidosis is also associated with inorganic aerosol exposures, particularly with several metal dusts. This association is not surprising, as $\mathrm{CBD}$ from beryllium exposure is a clinical mimic of sarcoidosis. Sarcoidosis is not only associated with 
TABLE 2 | Non-infectious environmental risk factors associated with sarcoidosis.

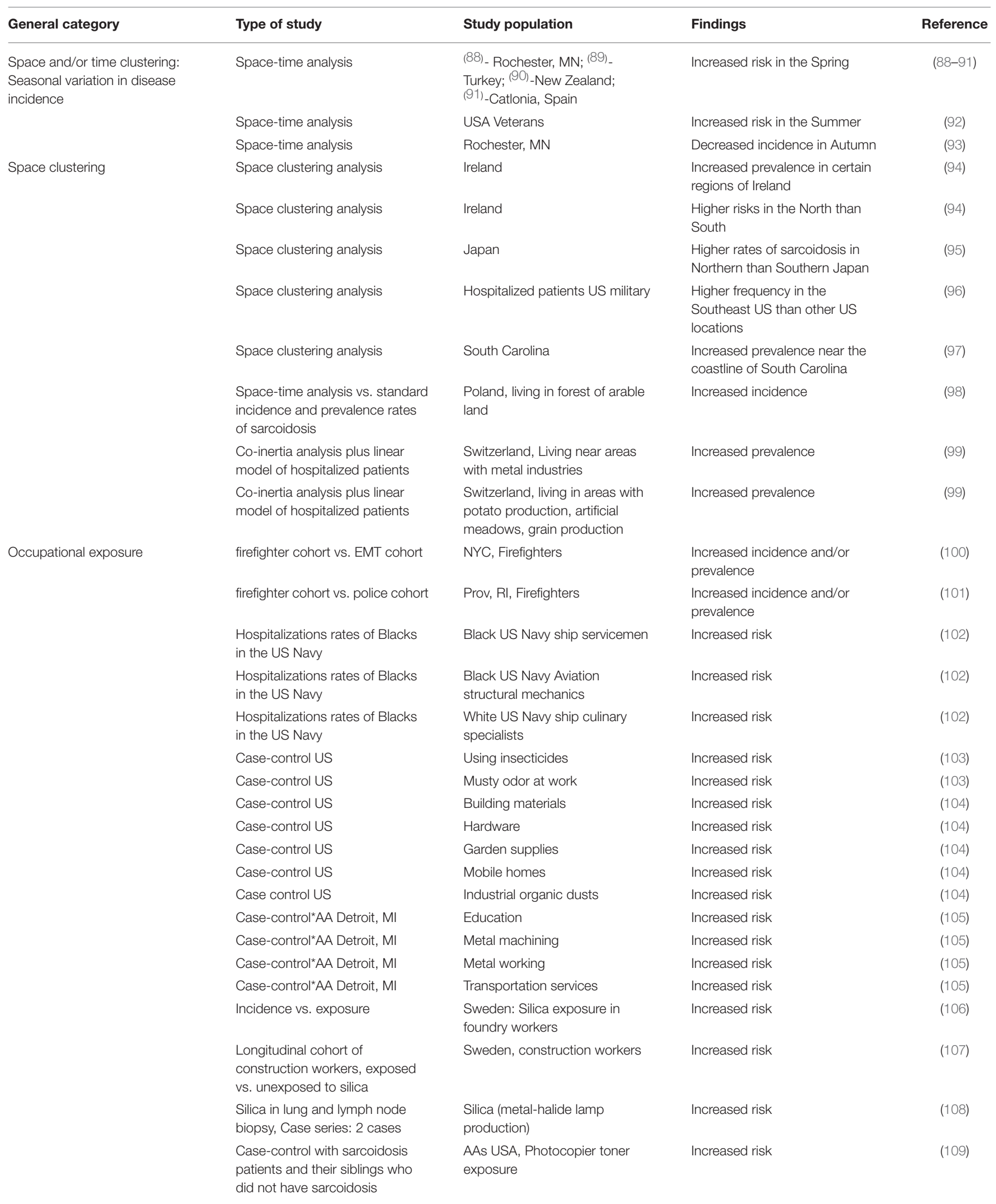


TABLE 2 | Continued

\begin{tabular}{|c|c|c|c|c|}
\hline General category & Type of study & Study population & Findings & Reference \\
\hline & $\begin{array}{l}\text { Tracking sarcoidosis incidence in } \\
\text { FDNY workers pre and post } \\
\text { WTC disaster }\end{array}$ & $\begin{array}{l}\text { NYC, World Trade Center dust } \\
\text { exposure }\end{array}$ & Increased incidence & $(110)$ \\
\hline & Case-controlAA Detroit MI & $\begin{array}{l}\text { AA Detroit MI, Working in high } \\
\text { humidity }\end{array}$ & Increased risk & $(105)$ \\
\hline & Case-ControlAA Detroit MI & $\begin{array}{l}\text { AA Detroit MI, Working with } \\
\text { titanium }\end{array}$ & Increased risk & $(105)$ \\
\hline & Case-ControlAA Detroit MI & $\begin{array}{l}\text { AA Detroit MI, Working with } \\
\text { vegetable dust }\end{array}$ & Increased risk & $(105)$ \\
\hline & $\begin{array}{l}\text { Elicited history of exposure and } \\
\text { analyzed lung biopsy specimens }\end{array}$ & Man-made mineral fibers & Increased risk & $(111)$ \\
\hline \multirow[t]{5}{*}{ Environmental exposure } & $\begin{array}{l}\text { Case-Control with dose } \\
\text { response SC }\end{array}$ & SC, Wood stove use & Increased risk & $(112)$ \\
\hline & $\begin{array}{l}\text { Case-Control with dose } \\
\text { response SC }\end{array}$ & SC, Fireplace use & Increased risk & $(112)$ \\
\hline & Case-ControlAA Detroit MI & AA Detroit MI, Musty odors & Increased risk & $(105)$ \\
\hline & Case-control SC & SC, Non-public water use & Increased risk & $(112)$ \\
\hline & Case-control SC & SC, Living/working on a farm & Increased risk & $(112)$ \\
\hline
\end{tabular}

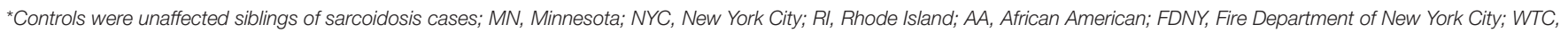
World Trade Center; SC, South Carolina.

several occupations directly involved with manipulations of metals $(102,105)$ but also more subtle exposures including photocopier toner (109) that contains copper, iron, and silica (114). One report found a significant association of man-made mineral fiber exposure and the development of sarcoidosis, and then went further to perform electron microscopy quantitative analysis on previous lung specimens in the sarcoidosis group and found that half of them silica, aluminum and/or titanium (111).

Exposure to combustible products, especially combustible wood, has been associated with the development of sarcoidosis. A prototypical example of this association is the high incidence and prevalence rates sarcoidosis that is observed in firefighters $(100,101)$. In one analysis, emergency medical technicians (EMTs) served as a control group to the firefighters because both groups went to fire sites (100). The annual incidence rate of sarcoidosis was extremely high $(44 / 100,000)$ in the firefighters whereas it was 0 in the EMTs. Wood stove use and fireplace use have also been associated with the development of sarcoidosis (112). The rigor of this association was strengthened by demonstrating a significant dose-response relationship of both wood stove and fireplace use to the frequency of sarcoidosis. Dust from the World Trade Center disaster has been associated with increased rates of developing sarcoidosis within the first 4 years after exposure (110). However, World Trade Center dust was a heterogenous exposure, and it is unclear whether the causative substance(s) was a combustible product, metal or gas.

Higher prevalence rates of sarcoidosis have been observed in Northern latitudes such as Northern Europe and Northern Japan, $(95,115)$ and it has been postulated that this relates to decreased sunlight exposure causing a deficiency in 1,25-dihydroxyvitamin $\mathrm{D}$ (116). A deficiency in 1,25-dihydroxy-vitamin D is associated with decreased production of the antimicrobial peptide cathelicidin that contributes to the development of infectious granulomatous diseases such as tuberculosis $(95,117)$. A relative deficiency in 1,25-dihydroxy-vitamin $\mathrm{D}$ may also explain the increased frequency of sarcoidosis in Blacks, as the ability to convert 7-dehydrocholesterol to previtamin D is suppressed because of skin pigmentation (118).

Some exposures associated with sarcoidosis are problematic to explain such as working in education (105) or the culinary arts (102). This may relate to the aforementioned concept that sarcoidosis may involve an initial portal of entry where a causative antigen first interacts with the immune system and then requires additional inflammatory modulation to cause disease. In an analysis that focused on mortality from sarcoidosis and not the incidence or prevalence of disease, women with sarcoidosis were more likely to have exposure from person-to-person contact (administration and banking) whereas men who were more likely to have inhalational exposures (119). This may explain why woman are more likely to develop non-pulmonary sarcoidosis than men, (20) and it might also explain how non-respiratory exposures may be mechanistically linked to the development of sarcoidosis.

\section{ANIMAL AND EXPERIMENTAL MODELS OF GRANULOMATOUS DISEASE}

Various animal and experimental models of granulomatous have been developed that have involved exposure to environmental substances (120). Carbon nanotube induced granulomatous lung disease has been demonstrated in an animal model and has shown several similarities to sarcoidosis $(121,122)$. Numerous components of infectious agents, particularly mycobacteria and Propionibacterium acnes have mimicked features of sarcoidosis 
in animal models (123-126). These models have demonstrated similar immune responses in terms of T-cell function and the production of cytokines seen in sarcoidosis (120).

\section{SUMMARY}

In conclusion, sarcoidosis is associated with several environmental exposures including infectious agents, noninfectious organic antigens, metals, combustible products, and other inorganic substances. These disparate exposures may suggest that sarcoidosis represents a collection of different disorders that all result in the development of a multisystem granulomatous disease. Alternatively, these varied exposures

\section{REFERENCES}

1. Baughman RP, Teirstein AS, Judson MA, Rossman MD, Yeager H, Bresnitz $\mathrm{EA}$, et al. Clinical characteristics of patients in a case control study of sarcoidosis. Am J Respir Crit Care Med. (2001) 164(10 Pt 1):18859. doi: 10.1164/ajrccm.164.10.2104046

2. Judson MA, Boan AD, Lackland DT. The clinical course of sarcoidosis: presentation, diagnosis, and treatment in a large white and black cohort in the United States. Sarcoidosis Vasc Diffuse Lung Dis. (2012) 29:119-27.

3. Ehlers S, Schaible UE. The granuloma in tuberculosis: dynamics of a host-pathogen collusion. Front Immunol. (2012) 3:411. doi: 10.3389/fimmu.2012.00411

4. Zumla A, James DG. Granulomatous infections: etiology and classification. Clin Infect Dis. (1996) 23:146-58. doi: 10.1093/clinids/23.1.146

5. Selman M, Pardo A, King TE. Hypersensitivity pneumonitis: insights in diagnosis and pathobiology. Am J Respir Crit Care Med. (2012). 186:31424. doi: 10.1164/rccm.201203-0513CI

6. Rossman MD. Chronic beryllium disease: diagnosis and management. Environ Health Perspect. (1996) 104(Suppl. 5):945-7. doi: 10.1289/ehp.96104s5945

7. Newman LS, Rose CS, Maier LA. Sarcoidosis. N Engl J Med. (1997) 336:122434. doi: 10.1056/NEJM199704243361706

8. Baughman RP, Culver DA, Judson MA. A concise review of pulmonary sarcoidosis. Am J Respir Crit Care Med. (2011) 183:573-81. doi: 10.1164/rccm.201006-0865CI

9. Moller DR, Chen ES. Genetic basis of remitting sarcoidosis: triumph of the trimolecular complex? Am J Respir Crit Care Med. (2002) 27:3915. doi: 10.1165/rcmb.2002-0164PS

10. Broos CE, Koth LL, van Nimwegen M, Veen JCCM, Paulissen SMJ, Hamburg JP, et al. Increased T-helper 17.1 cells in sarcoidosis mediastinal lymph nodes. Eur Respir J. (2018) 51:170112. doi: 10.1183/13993003.011 24-2017

11. Martinetti M, Luisetti M, Cuccia M. HLA and sarcoidosis: new pathogenetic insights. Sarcoidosis Vasc Diffuse Lung Dis. (2002) 19:83-95.

12. Du Bois R, Beirne PA, Anevlavis SE. Genetics. In: Drent $M$, Costabel U, editors. Sarcoidosis: European Respiratory Monograph. Sheffield: European respiroatry Society Journals Ltd. (2005). p. 64-81. doi: 10.1183/1025448x.00032005

13. Rossman MD, Thompson B, Frederick M, Maliarik M, Iannuzzi MC, Rybicki BA, et al. HLA-DRB1*1101: a significant risk factor for sarcoidosis in blacks and whites. Am J Hum Genet. (2003) 73:720-35. doi: 10.1086/378097

14. Mayer AS, Hamzeh N, Maier LA. Sarcoidosis and chronic beryllium disease: similarities and differences. Semin Respir Crit Care Med. (2014) 35:31629. doi: 10.1055/s-0034-1377059

15. Müller-Quernheim J, Gaede KI, Fireman E, Zissel G. Diagnoses of chronic beryllium disease within cohorts of sarcoidosis patients. Eur Respir J. (2006) 27:1190-5. doi: 10.1183/09031936.06.00112205

16. Van Dyke MV, Martyny JW, Mroz MM, Silveira LJ, Strand M, Fingerlin TE, et al. Risk of chronic beryllium disease by HLA-DPB1 E69 genotype and may each stimulate the immune system in different ways such that a specific immune pathway that leads to sarcoidosis is promoted. This could include the induction of autoimmunity. Genetics factors are most probably an important aspect of these mechanisms. Further insights concerning the relationship of environmental exposures to the development of sarcoidosis may have a major impact on the prevention and treatment of this enigmatic disease.

\section{AUTHOR CONTRIBUTIONS}

The author confirms being the sole contributor of this work and has approved it for publication.

beryllium exposure in nuclear workers. Am J Respir Crit Care Med. (2011) 183:1680-8. doi: 10.1164/rccm.201002-0254OC

17. Van Dyke MV, Martyny JW, Mroz MM, Silveira LJ, Strand M, Cragle DL, et al. Exposure and genetics increase risk of beryllium sensitisation and chronic beryllium disease in the nuclear weapons industry. Occup Environ Med. (2011) 68:842-8. doi: 10.1136/oem.2010.064220

18. Fontenot AP, Torres M, Marshall WH, Newman LS, Kotzin BL. Beryllium presentation to CD4+ T cells underlies disease-susceptibility HLA-DP alleles in chronic beryllium disease. Proc Natl Acad Sci USA. (2000) 97:1271722. doi: $10.1073 /$ pnas. 220430797

19. Tinkle SS, Schwitters PW, Newman LS. Cytokine production by bronchoalveolar lavage cells in chronic beryllium disease. Environ Health Perspect. (1996) 104(Suppl. 5):969-71. doi: 10.1289/ehp.96104s5969

20. James WE, Koutroumpakis E, Saha B, Nathani A, Saavedra L, Yucel RM, et al. Clinical Features of Extrapulmonary Sarcoidosis Without Lung Involvement. Chest. (2018) 154:349-56. doi: 10.1016/j.chest.2018.02.003

21. Kurata A, Terado Y, Izumi M, Fujioka Y, Franke FE. Where does the antigen of cutaneous sarcoidosis come from? J Cutan Pathol. (2010) 37:21121. doi: 10.1111/j.1600-0560.2009.01309.x

22. Bordignon M, Rottoli P, Agostini C, Alaibac M. Adaptive immune responses in primary cutaneous sarcoidosis. Clin Dev Immunol. (2011) 2011:235142. doi: 10.1155/2011/235142

23. Brinkman CC, Rouhani SJ, Srinivasan N, Engelhard VH. Peripheral tissue homing receptors enable $\mathrm{T}$ cell entry into lymph nodes and affect the anatomical distribution of memory cells. J Immunol. (2013) 191:241225. doi: 10.4049/jimmunol.1300651

24. Judson MA. A sarcoidosis clinician's perspective of MHC functional elements outside the antigen binding site. Hum Immunol. (2019) 80:859. doi: 10.1016/j.humimm.2018.05.007

25. Rossman MD, Thompson B, Frederick M, Iannuzzi MC, Rybicki BA, Pander JP, et al. HLA and environmental interactions in sarcoidosis. Sarcoidosis Vasc Diffuse Lung Dis. (2008) 25:125-32.

26. Zissel G, Muller-Quernheim J. Specific antigen(s) in sarcoidosis: a link to autoimmunity? Eur Respir J. (2016) 47:7079. doi: 10.1183/13993003.01791-2015

27. Häggmark A, Hamsten C, Wiklundh E, Lindskog C, Mattsson C, Andersson $\mathrm{E}$, et al. Proteomic profiling reveals autoimmune targets in sarcoidosis. Am J Respir Crit Care Med. (2015) 191:574-83. doi: 10.1164/rccm.201407-1341OC

28. Tchernev G, Lotti T, Cardoso JC, Kanazawa N, Guarneri C, Wollina $\mathrm{U}$. Cancer, infection and disturbances of the integrity of tissue homeostasis: the most significant triggers for molecular mimicry and autoimmunity in dermatology? Wien Med Wochenschr. (2014) 164:245-6. doi: 10.1007/s10354-014-0280-2

29. Tchernev G, Wollina U. Bacterial antigens and molecular mimicry: the bridging common problematic link in the pathogenesis of sarcoidosis and sarcoid-like reactions: isn't it time to wake up? Wien Med Wochenschr. (2014). 164:260-2. doi: 10.1007/s10354-014-0283-z

30. Kinloch AJ, Kaiser Y, Wolfgeher D, Ai J, Eklund A, Clark MR, et al. In situ humoral immunity to vimentin in HLA-DRB1*03(+) 
patients with pulmonary sarcoidosis. Front Immunol. (2018) 9:1516. doi: 10.3389/fimmu.2018.01516

31. Rojas M, Restrepo-Jimenez P, Monsalve DM, Pacheco Y, Acosta-Ampudia Y, Ramírez-Santana C, et al. Molecular mimicry and autoimmunity. $J$ Autoimmun. (2018) 95:100-23. doi: 10.1016/j.jaut.2018.10.012

32. Grunewald J, Kaiser Y, Ostadkarampour M, Rivera NV, Vezzi F, Lötstedt B, et al. T-cell receptor-HLA-DRB1 associations suggest specific antigens in pulmonary sarcoidosis. Eur Respir J. (2016) 47:898-909. doi: 10.1183/13993003.01209-2015

33. Eberhardt C, Thillai M, Parker R, Siddiqui N, Potiphar L, Goldin R, et al. Proteomic analysis of kveim reagent identifies targets of cellular immunity in sarcoidosis. PLoS ONE. (2017) 12:e0170285. doi: 10.1371/journal.pone.0170285

34. Heyder T, Kohler M, Tarasova NK, Haag S, Rutishauser D, Rivera NV, et al. Approach for identifying human leukocyte antigen (HLA)-DR bound peptides from scarce clinical samples. Mol Cell Proteomics. (2016) 15:301729. doi: $10.1074 /$ mcp.M116.060764

35. Wahlström J, Dengjel J, Winqvist O, Targoff I, Persson B, Duyar H, et al. Autoimmune $\mathrm{T}$ cell responses to antigenic peptides presented by bronchoalveolar lavage cell HLA-DR molecules in sarcoidosis. Clin Immunol. (2009) 133:353-63. doi: 10.1016/j.clim.2009.08.008

36. Wahlström J, Dengjel J, Persson B, Duyar H, Rammensee HG, Stevanović $S$, et al. Identification of HLA-DR-bound peptides presented by human bronchoalveolar lavage cells in sarcoidosis. J Clin Invest. (2007) 117:357682. doi: 10.1172/JCI32401

37. Fontenot AP, Falta MT, Kappler JW, Dai S, McKee AS. Berylliuminduced hypersensitivity: genetic susceptibility and neoantigen generation. J Immunol. (2016) 196:22-7. doi: 10.4049/jimmunol.1502011

38. Kobak S, Yilmaz H, Sever F, Duran A, Sen N, Karaarslan A. The prevalence of antinuclear antibodies in patients with sarcoidosis. Autoimmune Dis. (2014) 2014:351852. doi: 10.1155/2014/351852

39. Dengjel J, Schoor O, Fischer R, Reich M, Kraus M, Müller M, et al. Autophagy promotes MHC class II presentation of peptides from intracellular source proteins. Proc Natl Acad Sci USA. (2005) 102:79227. doi: 10.1073/pnas.0501190102

40. Gkiozos I, Kopitopoulou A, Kalkanis A, Vamvakaris IN, Judson MA, Syrigos KN. Sarcoidosis-like reactions induced by checkpoint inhibitors. J Thorac Oncol. (2018) 13:1076-82. doi: 10.1016/j.jtho.2018.04.031

41. Le Burel S, Champiat S, Mateus C, Marabelle A, Michot JM, Robert C, et al. Prevalence of immune-related systemic adverse events in patients treated with anti-Programmed cell Death 1/anti-Programmed cell Death-Ligand 1 agents: a single-centre pharmacovigilance database analysis. Eur J Cancer. (2017) 82:34-44. doi: 10.1016/j.ejca.2017.05.032

42. Arkema EV, Cozier YC. Epidemiology of sarcoidosis: current findings and future directions. Ther Adv Chronic Dis. (2018) 9:227-40. doi: 10.1177/2040622318790197

43. Rossides M, Grunewald J, Eklund A, Kullberg S, Di Giuseppe D, Askling J, et al. Familial aggregation and heritability of sarcoidosis: a Swedish nested case-control study. Eur Respir J. (2018) 52:1800385. doi: 10.1183/13993003.00385-2018

44. Levin AM, Iannuzzi MC, Montgomery CG, Trudeau S, Datta I, McKeigue $\mathrm{P}$, et al. Association of ANXA11 genetic variation with sarcoidosis in African Americans and European Americans. Genes Immun. (2013) 14:138. doi: 10.1038 /gene. 2012.48

45. Adrianto I, Lin CP, Hale JJ, Levin AM, Datta I, Parker R, et al. Genome-wide association study of African and European Americans implicates multiple shared and ethnic specific loci in sarcoidosis susceptibility. PLoS ONE. (2012) 7:e43907. doi: 10.1371/journal.pone.0043907

46. Morais A, Lima B, Peixoto MJ, Alves H, Marques A, Delgado L. BTNL2 gene polymorphism associations with susceptibility and phenotype expression in sarcoidosis. Respir Med. (2012) 106:1771-7. doi: 10.1016/j.rmed.2012.08.009

47. Esteves T, Aparicio G, Garcia-Patos V. Is there any association between Sarcoidosis and infectious agents?: a systematic review and meta-analysis. BMC Pulm Med. (2016) 16:165. doi: 10.1186/s12890-016-0332-z

48. Fang $\mathrm{C}$, Huang $\mathrm{H}, \mathrm{Xu} \mathrm{Z}$. Immunological evidence for the role of mycobacteria in sarcoidosis: a meta-analysis. PLoS ONE. (2016) 11:e0154716. doi: 10.1371/journal.pone.0154716
49. Lee H, Eom M, Kim SH, Wang HY, Lee H, Choi EH. Identification of Mycobacterium tuberculosis and non-tuberculous mycobacteria from cutaneous sarcoidosis lesions by reverse blot hybridization assay. J Dermatol. (2019) 46:917-21. doi: 10.1111/1346-8138.15042

50. Goyal B, Sheikh JA, Agarwal R, Verma I. Levels of circulating immune complexes containing Mycobacterium Tuberculosis-specific antigens in pulmonary tuberculosis and sarcoidosis patients. Indian J Med Microbiol. (2017) 35:290-2. doi: 10.4103/0255-0857.209569

51. Rotsinger JE, Celada LJ, Polosukhin VV, Atkinson JB, Drake WP. Molecular analysis of sarcoidosis granulomas reveals antimicrobial targets. Am J Respir Cell Mol Biol. (2016) 55:128-34. doi: 10.1165/rcmb.2015-0212OC

52. Eishi Y, Suga M, Ishige I, Kobayashi D, Yamada T, Takemura T, et al. Quantitative analysis of mycobacterial and propionibacterial DNA in lymph nodes of Japanese and European patients with sarcoidosis. J Clin Microbiol. (2002) 40:198-204. doi: 10.1128/JCM.40.1.198-204.2002

53. Milman N, Lisby G, Friis S, Kemp L. Prolonged culture for mycobacteria in mediastinal lymph nodes from patients with pulmonary sarcoidosis. A negative study. Sarcoidosis Vasc Diffuse Lung Dis. (2004) 21:25-8.

54. Song Z, Marzilli L, Greenlee BM, Chen ES, Silver RF, Askin FB, et al. Mycobacterial catalase-peroxidase is a tissue antigen and target of the adaptive immune response in systemic sarcoidosis. J Exp Med. (2005) 201:755-67. doi: 10.1084/jem.20040429

55. Chen ES, Wahlström J, Song Z, Willett MH, Wikén M, Yung RC, et al. $\mathrm{T}$ cell responses to mycobacterial catalase-peroxidase profile a pathogenic antigen in systemic sarcoidosis. J Immunol. (2008) 181:878496. doi: $10.4049 /$ jimmunol.181.12.8784

56. Drake WP, Dhason MS, Nadaf M, Shepherd BE, Vadivelu S, Hajizadeh R, et al. Cellular recognition of Mycobacterium tuberculosis ESAT-6 and KatG peptides in systemic sarcoidosis. Infect Immun. (2007) 75:52730. doi: 10.1128/IAI.00732-06

57. Oswald-Richter KA, Culver DA, Hawkins C, Hajizadeh R, Abraham S, Shepherd BE, et al. Cellular responses to mycobacterial antigens are present in bronchoalveolar lavage fluid used in the diagnosis of sarcoidosis. Infect Immun. (2009) 77:3740-8. doi: 10.1128/IAI.00142-09

58. Homma JY, Abe C, Chosa H, Ueda K, Saegusa J, Nakayama M, et al. Bacteriological investigation on biopsy specimens from patients with sarcoidosis. Jpn J Exp Med. (1978) 48:251-5.

59. Abe C, Iwai K, Mikami R, Hosoda Y. Frequent isolation of Propionibacterium acnes from sarcoidosis lymph nodes. Zentralbl Bakteriol Mikrobiol Hyg A. (1984) 256:541-7. doi: 10.1016/S0174-3031(84)80032-3

60. Nagata K, Eishi Y, Uchida K, Yoneda K, Hatanaka H, Yasuhara T, et al. Immunohistochemical detection of propionibacterium acnes in the retinal granulomas in patients with ocular sarcoidosis. Sci Rep. (2017) 7:15226. doi: 10.1038/s41598-017-15710-0

61. Suzuki Y, Uchida K, Takemura T, Sekine M, Tamura T, Furukawa A, et al. Propionibacterium acnes-derived insoluble immune complexes in sinus macrophages of lymph nodes affected by sarcoidosis. PLoS ONE. (2018) 13:e0192408. doi: 10.1371/journal.pone.0192408

62. Hajizadeh R, Sato H, Carlisle J, Nadaf MT, Evans W, Shepherd BE, et al. Mycobacterium tuberculosis Antigen $85 \mathrm{~A}$ induces Th-1 immune responses in systemic sarcoidosis. J Clin Immunol. (2007) 27:44554. doi: 10.1007/s10875-007-9080-4

63. Dubaniewicz A, Dubaniewicz-Wybieralska M, Sternau A, Zwolska Z, IzyckaSwieszewska E, Augustynowicz-Kopec E, et al. Mycobacterium tuberculosis complex and mycobacterial heat shock proteins in lymph node tissue from patients with pulmonary sarcoidosis. J Clin Microbiol. (2006) 44:344851. doi: 10.1128/JCM.01433-06

64. Carlisle J, Evans W, Hajizadeh R, Nadaf M, Shepherd B, Ott RD, et al. Multiple Mycobacterium antigens induce interferon-gamma production from sarcoidosis peripheral blood mononuclear cells. Clin Exp Immunol. (2007) 150:460-8. doi: 10.1111/j.1365-2249.2007.03510.x

65. Nakata Y, Ejiri T, Kishi T, Mori Y, Hioka T, Kataoka M, et al. Alveolar lymphocyte proliferation induced by Propionibacterium acnes in sarcoidosis patients. Acta Med Okayama. (1986) 40:257-64.

66. Furusawa H, Suzuki Y, Miyazaki Y, Inase N, Eishi Y. Th1 and Th17 immune responses to viable Propionibacterium acnes in patients with sarcoidosis. Respir Investig. (2012) 50:104-9. doi: 10.1016/j.resinv.2012.07.001 
67. Terčelj M, Stopinšek S, Ihan A, Salobir B, Simčič S, Wraber B, et al. In vitro and in vivo reactivity to fungal cell wall agents in sarcoidosis. Clin Exp Immunol. (2011) 166:87-93. doi: 10.1111/j.1365-2249.2011.04456.x

68. Suchankova M, Paulovicova E, Paulovicova L, Majer I, Tedlova E, Novosadova $\mathrm{H}$, et al. Increased antifungal antibodies in bronchoalveolar lavage fluid and serum in pulmonary sarcoidosis. Scand J Immunol. (2015) 81:259-64. doi: 10.1111/sji.12273

69. Ishihara $\mathrm{M}$, Ohno $\mathrm{S}$, Ono $\mathrm{H}$, Isogai $\mathrm{E}$, Kimura $\mathrm{K}$, Isogai $\mathrm{H}$, et al. Seroprevalence of anti-Borrelia antibodies among patients with confirmed sarcoidosis in a region of Japan where Lyme borreliosis is endemic. Graefes Arch Clin Exp Ophthalmol. (1998) 236:280-4. doi: 10.1007/s004170050078

70. Xu Z, Ma D, Luo W, Zhu Y. Detection of Borrelia burgdorferi DNA in granulomatous tissues from patients with sarcoidosis using polymerase chain reaction in situ technique. Chin Med Sci J. (1996) 11:220-3.

71. Lian W, Luo W. Borrelia burgdorferi DNA in biological samples from patients with sarcoidosis using the polymerase chain reaction technique. Chin Med Sci J. (1995) 10:93-5.

72. Drake WP, Richmond BW, Oswald-Richter K, Yu C, Isom JM, Worrell JA, et al. Effects of broad-spectrum antimycobacterial therapy on chronic pulmonary sarcoidosis. Sarcoidosis Vasc Diffuse Lung Dis. (2013) 30:201-11.

73. Drake WP, Oswald-Richter K, Richmond BW, Isom J, Burke VE, Algood $\mathrm{H}$, et al. Oral antimycobacterial therapy in chronic cutaneous sarcoidosis: a randomized, single-masked, placebo-controlled study. JAMA Dermatol. (2013) 149:1040-9. doi: 10.1001/jamadermatol.2013.4646

74. Steen T, English JC. Oral minocycline in treatment of cutaneous sarcoidosis. JAMA Dermatol. (2013) 149:758-60. doi: 10.1001/jamadermatol.2013.2977

75. Bachelez H, Senet P, Cadranel J, Kaoukhov A, Dubertret L. The use of tetracyclines for the treatment of sarcoidosis. Arch Dermatol. (2001) 137:6973. doi: 10.1001/archderm.137.1.69

76. Miyazaki E, Ando M, Fukami T, Nureki S, Eishi Y, Kumamoto T. Minocycline for the treatment of sarcoidosis: is the mechanism of action immunomodulating or antimicrobial effect? Clin Rheumatol. (2008) 27:1195-7. doi: 10.1007/s10067-008-0903-3

77. Takemori N, Nakamura M, Kojima M, Eishi Y. Successful treatment in a case of Propionibacterium acnes-associated sarcoidosis with clarithromycin administration: a case report. J Med Case Rep. (2014) 8:15. doi: 10.1186/1752-1947-8-15

78. Tercelj M, Salobir B, Zupancic M, Rylander R. Antifungal medication is efficient in the treatment of sarcoidosis. Ther Adv Respir Dis. (2011) 5:15762. doi: 10.1177/1753465811401648

79. Inaoka PT, Shono M, Kamada M, Espinoza JL. Host-microbe interactions in the pathogenesis and clinical course of sarcoidosis. J Biomed Sci. (2019) 26:45. doi: 10.1186/s12929-019-0537-6

80. Espinoza JL, Minami M. Sensing bacterial-induced DNA damaging effects via natural killer group 2 member D immune receptor: from dysbiosis to autoimmunity and carcinogenesis. Front Immunol. (2018) 9:52. doi: 10.3389/fimmu.2018.00052

81. Kriss M, Hazleton KZ, Nusbacher NM, Martin CG, Lozupone CA. Low diversity gut microbiota dysbiosis: drivers, functional implications and recovery. Curr Opin Microbiol. (2018) 44:3440. doi: 10.1016/j.mib.2018.07.003

82. Costa AN, Costa FMD, Campos SV, Salles RK, Athanazio RA. The pulmonary microbiome: challenges of a new paradigm. J Bras Pneumol. (2018) 44:424-32. doi: 10.1590/s1806-37562017000000209

83. Sulaiman I, Wu BG, Li Y, Scott AS, Malecha P, Scaglione B, et al. Evaluation of the airway microbiome in nontuberculous mycobacteria disease. Eur Respir J. (2018) 52:1800810. doi: 10.1183/13993003.00810-2018

84. Garzoni C, Brugger SD, Qi W, Wasmer S, Cusini A, Dumont P, et al. Microbial communities in the respiratory tract of patients with interstitial lung disease. Thorax. (2013) 68:1150-6. doi: 10.1136/thoraxjnl-2012-202917

85. Clarke EL, Lauder AP, Hofstaedter CE, Hwang Y, Fitzgerald AS, Imai I, et al. Microbial Lineages in Sarcoidosis. A Metagenomic Analysis Tailored for Low-Microbial Content Samples. Am J Respir Crit Care Med. (2018) 197:225-34. doi: 10.1164/rccm.201705-08910C

86. Zimmermann A, Knecht $H$, Häsler R, Zissel G, Gaede KI, Hofmann S, et al. Atopobium and Fusobacterium as novel candidates for sarcoidosis-associated microbiota. Eur Respir J. (2017) 50:1600746. doi: 10.1183/13993003.00746-2016
87. Scher JU, Joshua V, Artacho A, Abdollahi-Roodsaz S, Öckinger J, Kullberg S, et al. The lung microbiota in early rheumatoid arthritis and autoimmunity. Microbiome. (2016) 4:60. doi: 10.1186/s40168-016-0206-x

88. Henke CE, Henke G, Elveback LR, Beard CM, Ballard DJ, Kurland LT. The epidemiology of sarcoidosis in Rochester, Minnesota: a populationbased study of incidence and survival. Am J Epidemiol. (1986) 123:8405. doi: 10.1093/oxfordjournals.aje.a114313

89. Demirkok SS, Basaranoglu M, Coker E, Karayel T. Seasonality of the onset of symptoms, tuberculin test anergy and Kveim positive reaction in a large cohort of patients with sarcoidosis. Respirology. (2007) 12:5913. doi: 10.1111/j.1440-1843.2007.01062.x

90. Wilsher ML. Seasonal clustering of sarcoidosis presenting with erythema nodosum. Eur Respir J. (1998) 12:11979. doi: 10.1183/09031936.98.12051197

91. Fité E, Alsina JM, Mañá J, Pujol R, Ruiz J, Morera J. Epidemiology of sarcoidosis in Catalonia: 1979-1989. Sarcoidosis Vasc Diffuse Lung Dis. (1996) 13:153-8.

92. Gupta D, Agarwal R, Aggarwal AN. Seasonality of sarcoidosis: the 'heat' is on. Sarcoidosis Vasc Diffuse Lung Dis. (2013) 30:241-3.

93. Ungprasert P, Crowson CS, Matteson EL. Seasonal variation in incidence of sarcoidosis: a population-based study, 1976-2013. Thorax. (2016) 71:11646. doi: 10.1136/thoraxjnl-2016-209032

94. Nicholson TT, Plant BJ, Henry MT, Bredin CP. Sarcoidosis in Ireland: regional differences in prevalence and mortality from 1996-2005. Sarcoidosis Vasc Diffuse Lung Dis. (2010) 27:111-20.

95. Hosoda Y, Sasagawa S, Yamaguchi T. Sarcoidosis and tuberculosis: epidemiological similarities and dissimilarities. A review of a series of studies in a Japanese work population. (1941-1996) and the general population (1959-1984). Sarcoidosis Vasc Diffuse Lung Dis. (2004). 21:85-93.

96. McDonough C, Gray GC. Risk factors for sarcoidosis hospitalization among U.S. Navy and Marine Corps personnel, 1981 to 1995. Mil Med. (2000). 165:630-2. doi: 10.1093/milmed/165.8.630

97. Kajdasz DK, Judson MA, Mohr LC, Lackland DT. Geographic variation in sarcoidosis in South Carolina: its relation to socioeconomic status and health care indicators. Am J Epidemiol. (1999) 150:271-8. doi: 10.1093/oxfordjournals.aje.a009998

98. Kowalska M, Niewiadomska E, Zejda JE. Epidemiology of sarcoidosis recorded in 2006-2010 in the Silesian voivodeship on the basis of routine medical reporting. Ann Agric Environ Med. (2014) 21:55-8.

99. Deubelbeiss U, Gemperli A, Schindler C, Baty F, Brutsche MH. Prevalence of sarcoidosis in Switzerland is associated with environmental factors. Eur Respir J. (2010) 35:1088-97. doi: 10.1183/09031936.00197808

100. Prezant DJ, Dhala A, Goldstein A, Janus D, Ortiz F, Aldrich TK, et al. The incidence, prevalence, and severity of sarcoidosis in New York City firefighters. Chest. (1999) 116:1183-93. doi: 10.1378/chest.116.5.1183

101. Kern DG, Neill MA, Wrenn DS, Varone JC. Investigation of a unique timespace cluster of sarcoidosis in firefighters. Am Rev Respir Dis. (1993) 148(4 Pt 1):974-80. doi: 10.1164/ajrccm/148.4_Pt_1.974

102. Gorham ED, Garland CF, Garland FC, Kaiser K, Travis WD, Centeno JA. Trends and occupational associations in incidence of hospitalized pulmonary sarcoidosis and other lung diseases in Navy personnel: a 27-year historical prospective study, 1975-2001. Chest. (2004) 126:14318. doi: $10.1378 /$ chest.126.5.1431

103. Newman LS, Rose CS, Bresnitz EA, Rossman MD, Barnard J, Frederick $\mathrm{M}$, et al. A case control etiologic study of sarcoidosis: environmental and occupational risk factors. Am J Respir Crit Care Med. (2004) 170:132430. doi: 10.1164/rccm.200402-249OC

104. Barnard J, Rose C, Newman L, Canner M, Martyny J, McCammon C, et al. Job and industry classifications associated with sarcoidosis in A CaseControl Etiologic Study of Sarcoidosis (ACCESS). J Occup Environ Med. (2005) 47:226-34. doi: 10.1097/01.jom.0000155711.88781.91

105. Kucera GP, Rybicki BA, Kirkey KL, Coon SW, Major ML, Maliarik MJ, et al. Occupational risk factors for sarcoidosis in African-American siblings. Chest. (2003) 123:1527-35. doi: 10.1378/chest.123.5.1527

106. Vihlborg P, Bryngelsson IL, Andersson L, Graff P. Risk of sarcoidosis and seropositive rheumatoid arthritis from occupational silica exposure in Swedish iron foundries: a retrospective cohort study. BMJ Open. (2017) 7:e016839. doi: 10.1136/bmjopen-2017-016839 
107. Jonsson E, Järvholm B, Andersson M. Silica dust and sarcoidosis in Swedish construction workers. Occup Med. (2019) 69:4826. doi: $10.1093 /$ occmed/kqz118

108. Ronsmans S, Verbeken EK, Adams E, Keirsbilck S, Yserbyt J, Wuyts WA, et al. Granulomatous lung disease in two workers making light bulbs. Am J Ind Med. (2019) 62:908-3. doi: 10.1002/ajim.23030

109. Rybicki BA, Amend KL, Maliarik MJ, Iannuzzi MC. Photocopier exposure and risk of sarcoidosis in African-American sibs. Sarcoidosis Vasc Diffuse Lung Dis. (2004) 21:49-55. doi: 10.1007/s11083-004-2862-x

110. Izbicki G, Chavko R, Banauch GI, Weiden MD, Berger KI, Aldrich TK, et al. World Trade Center "sarcoid-like" granulomatous pulmonary disease in New York City Fire Department rescue workers. Chest. (2007) 131:141423. doi: $10.1378 /$ chest.06-2114

111. Drent M, Bomans PH, Van Suylen RJ, Lamers RJ, Bast A, Wouters EF. Association of man-made mineral fibre exposure and sarcoidlike granulomas. Respir Med. (2000) 94:815-20. doi: 10.1053/rmed.2000.0827

112. Kajdasz DK, Lackland DT, Mohr LC, Judson MA. A current assessment of rurally linked exposures as potential risk factors for sarcoidosis. Ann Epidemiol. (2001) 11:111-7. doi: 10.1016/S1047-2797(00) 00179-4

113. Nakajima A, Saraya $T$, Mori $T$, Ikeda $R$, Sugita $T$, Watanabe $T$, et al. Familial summer-type hypersensitivity pneumonitis in Japan: two case reports and review of the literature. BMC Res Notes. (2013) 6:371. doi: 10.1186/1756-0500-6-371

114. Armbruster C, Dekan G, Hovorka A. Granulomatous pneumonitis and mediastinal lymphadenopathy due to photocopier toner dust. Lancet. (1996) 348:690. doi: 10.1016/S0140-6736(05)65119-7

115. Arkema EV, Grunewald J, Kullberg S, Eklund A, Askling J. Sarcoidosis incidence and prevalence: a nationwide register-based assessment in Sweden. Eur Respir J. (2016) 48:1690-9. doi: 10.1183/13993003.004 77-2016

116. Sawahata M, Sugiyama Y. An epidemiological perspective of the pathology and etiology of sarcoidosis. Sarcoidosis Vasc Diffuse Lung Dis. (2016) 33:112-6.

117. Hill AB. The environment and disease: association or causation? (1965). J R Soc Med. (2015). 108:32-7. doi: 10.1177/0141076814562718

118. Harris SS. Vitamin D and African Americans. J Nutr. (2006) 136:11269. doi: $10.1093 / \mathrm{jn} / 136.4 .1126$
119. Yanardag H, Pamuk ON, Karayel T. Cutaneous involvement in sarcoidosis: analysis of the features in 170 patients. Respir Med. (2003) 97:97882. doi: 10.1016/S0954-6111(03)00127-6

120. Hu Y, Yibrehu B, Zabini D, Kuebler WM. Animal models of sarcoidosis. Cell Tissue Res. (2017) 367:651-61. doi: 10.1007/s00441-016-2526-3

121. Barna BP, Judson MA, Thomassen MJ. Carbon Nanotubes and Chronic Granulomatous Disease. Nanomaterials. (2014) 4:508-21. doi: 10.3390/nano4020508

122. Barna BP, Huizar I, Malur A, McPeek M, Marshall I, Jacob M, et al. Carbon nanotube-induced pulmonary granulomatous disease: Twist1 and alveolar macrophage M1 activation. Int J Mol Sci. (2013) 14:2385871. doi: 10.3390/ijms141223858

123. Chen ES, Song Z, Willett MH, Heine S, Yung RC, Liu MC, et al. Serum amyloid A regulates granulomatous inflammation in sarcoidosis through Toll-like receptor-2. Am J Respir Crit Care Med. (2010) 181:36073. doi: 10.1164/rccm.200905-0696OC

124. Herndon B, Quinn T, Wasson N, Nzabi M, Molteni A. Urease and Helicobacter spp. antigens in pulmonary granuloma. J Comp Pathol. (2013) 148:266-77. doi: 10.1016/j.jcpa.2012.06.011

125. Swaisgood CM, Oswald-Richter K, Moeller SD, Klemenc JM, Ruple LM, Farver CF, et al. Development of a sarcoidosis murine lung granuloma model using Mycobacterium superoxide dismutase A peptide. Am J Respir Cell Mol Biol. (2011) 44:166-74. doi: 10.1165/rcmb.2009-0350OC

126. Werner JL, Escolero SG, Hewlett JT, Mak TN, Williams BP, Eishi Y, et al. Induction of pulmonary granuloma formation by propionibacterium acnes is regulated by MyD88 and Nox2. Am J Respir Cell Mol Biol. (2017) 56:12130. doi: $10.1165 / \mathrm{rcmb} .2016-0035 \mathrm{OC}$

Conflict of Interest: The author declares that the research was conducted in the absence of any commercial or financial relationships that could be construed as a potential conflict of interest.

Copyright (C) 2020 Judson. This is an open-access article distributed under the terms of the Creative Commons Attribution License (CC BY). The use, distribution or reproduction in other forums is permitted, provided the original author(s) and the copyright owner(s) are credited and that the original publication in this journal is cited, in accordance with accepted academic practice. No use, distribution or reproduction is permitted which does not comply with these terms. 